\title{
PKM Pendampingan Perilaku Hidup Sehat Santri PP. Nurul Jadid di Masa New Normal
}

Khodijatul Qodriyah ${ }^{1 *}$, Ainun Nabila Syafitri ${ }^{2}$, Tamara Maylyana Putri ${ }^{3}$, Nur Miswatul Yulianti ${ }^{4}$, Sawiyatin Rofiah ${ }^{5}$, Wahyu Maulidi ${ }^{6}$, Sri Ayu Putri Ningtias ${ }^{7}$, Lailatus Syarifah ${ }^{8}$, Zahra ${ }^{9}$, Aviah Asmaul Hosna ${ }^{10}$, Nur Madatillah ${ }^{11}$

Universitas Nurul Jadid Probolinggo $1,2,3,4,5,6,7,8,9,10,11$

\{iahhamid@gmail.com \}

Submission: 11/09/2021 Received: 31/12/2021 Published: 31/12/2021

Katakunci:

Pola hidup sehat, santri, new normal

\begin{abstract}
Abstrak. Saat ini Indonesia sedang mengalami Pandemic Covid-19. Covid-19 merupakan suatu penyakit menular yang disebabkan oleh coronavirus yang baru ditemukan. Virus corona dapat menginfeksi pada sistem pernafasan yang dapat di identifikasi seperti penyakit flu biasa sampai penyakit pernafasan yang semakin parah. Covid-19 oleh WHO dinyatakan sebagai Pandemi dan menyebabkan perubahan dalam tatanan kehidupan manusia begitupun kehidupan santri di PP. Nurul Jadid. Di masa new normal ini PP. Nurul Jadid telah melakukan berbagai upaya untuk mencegah penyebaran virus corona, diantaranya pembentukan tim gugus covid pesantren, menerapkan social distancing. Kegiatan PKM ini bertujuan untuk memberikan pelatihan, sosialisasi dan pendampingan kepada santri dan pengurus PP. Nurul Jadid agar dapat memahami dan menerapkan pola hidup sehat untuk mencegah penyebaran covid-19. Hasil yang dicapai dalam PKM ini adalah meningkatnya keterampilan pengurus dalam menciptakan berbagai media sosialisasi yang menarik dan mudah dipahami oleh santri. Melalui kegiatan sosialisasi, santri memiliki pemahaman dan dapat menerapkan pola hidup sehat dalam kegiatan rutin sehari-hari. Impelementasi hasil pelatihan dan sosialisai dalam kegiata PKM ini juga telah diintegrasikan dalam program kegiatan rutin santri dan telah menjadi bagian dari sistem kebijakan pesantren.
\end{abstract}

\section{Pendahuluan}

Coronavirus Disease 2019 (Covid-19) adalah penyakit menular yang disebabkan oleh Severe Acute Respiratory Syndrome Coronavirus 2 (SARSCoV-2). SARS-CoV-2 merupakan coronavirus jenis baru yang belum pernah diidentifikasi sebelumnya pada manusia. Dalam Pedoman Pencegahan dan Pengendalian Covid-19 Kementerian Kesehatan RI disebutkan bahwa setidaknya ada dua jenis coronavirus yang dapat menimbulkan gejala berat 
seperti Middle East Respiratory Syndrome atau MERS dan Severe Acute Respiratory Syndrome atau SARS (Isbaniah, F. et al. 2020).

Covid-19 menjadi ancaman kesehatan secara global di seluruh negara di dunia, telah menyebar dan dinyatakan sebagai pandemi global sejak 11 Maret 2020 (Astawan, M, 2020) dan menjadi ancaman kesehatan dunia dan sejak itulah Covid-19 mempengaruhi seluruh sendi-sendi kehidupan masyarakat dunia diberbagai sektor diantaranya, sektor ekonomi, sektor pendidikan, sektor politik, sektor perindustrian dan sebagainya, sehingga diperlukan strategi dan upaya yang komprehensif dalam percepatan penanganan COVID-19. Pembatasan Sosial Berskala Besar (PSBB) dilakukan salah satunya dengan meliburkan tempat kerja, sehingga kian berdampak pada aspek ekonomi, sehingga di tetapkan gaya hidup new normal, dengan dapat beraktifitas diluar tapi dengan protokol kesehatan, atau hal lain yang dapat diperhatikan (Kemenkes RI, 2020).

Situasi dampak Covid-19 yang begitu besar dan masanya yang tidak dapat diprediksi maka pemerintah mengambil langkah agar bisa berdampingan dengan Covid-19 (Habibi, A. 2020). Dampak dari langkah pemerintah ini mengharuskan masyarakat melakukan pola hidup dan kebiasaan baru dalam upaya pengendalian dan pencegahan baik dalam kehidupan terbatas maupun dalam melakukan aktifitas publik melalui peningkatan daya tahan tubuh masing-masing perorangan melalui pembiasaan hidup sehat dengan menjaga kebersihan, menjaga asupan gizi dan nutrisi makanan, serta menjaga daya tahan tubuh dengan rutin berolahraga di pagi hari.

Pemerintah Indonesia melalui Kementerian Kesehatan telah berupaya untuk melakukan penanggulangan Covid-19 ini dengan berbagai kebijakan salah satunya menjadikan Indonesia menuju kehidupan baru atau dikenal dengan New Normal. Di kehidupan baru ini masyarakat yang harus sadar menjalani setiap langkah kehidupan menjadi lebih teratur, aktif, kreatif bahkan harus mampu menyesuaikan dengan kebutuhan lingkungan sekitar (S. Y. Amijaya, dkk., 2020), diantaranya melalui program seperti social distancing, isolasi mandiri, dan menerapkan pola hidup bersih dan sehat (PHBS) seperti sering mencuci tangan dengan sabun, menggunakan masker, konsumsi gizi seimbang, perbanyak buah dan sayur, rajin olahraga dan cukup istirahat, berhati-hati kontak dengan hewan dan jangan mengkonsumsi daging yang tidak dimasak. Gerakan PHBS bertujuan untuk meningkatkan 
kualitas kesehatan melalui proses penyadaran agar setiap individu dapat menjalani perilaku kehidupan sehari-hari yang bersih dan sehat agar terhindar dari berbagai macam penyakit (Kemenkes, 2020).

Kebijakan new normal yang dikeluarkan pemerintah pada bulan Juni merupakan langkah yang ditempuh agar aktivitas di bidang pendidikan dalam mencerdaskan kehidupan bangsa tidak terhenti, tidak terkecuali aktivitas pendidikan dan belajar mengajar di pondok pesantren. Keberadaan pondok pesantren memiliki kontribusi positif dalam pembangunan NKRI. Keberadaan pondok pesantren di Indonesia memiliki kontribusi sangat besar, baik bagi kemajuan Islam itu sendiri maupun bagi kehidupan bangsa Indonesia. Hal ini dapat dilihat dari kiprah para Kyai dan santrinya dalam perjuangan kemerdekaan bangsa Indonesia maupun pada masa pembangunan dan reformasi yang saat ini sedang berlangsung (Wahyudin, 2017).

Pondok Pesantren Nurul Jadid merupakan salah satu pondok pesantren yang ada di kecamatan Paiton Kabupaten Probolinggo. Dalam rangka pencegahan Covid-19 Pondok Pesantren Nurul Jadid telah mendirikan Gugus Covid sebagai unit lembaga baru di bawah Klinik Azzainiyah yang memiliki tugas khusus untuk melakukan layanan dan program-program pencegahan dan penularan Covid-19 di lingkungan santri Pondok Pesantren Nurul Jadid (Susanto, S.,2020, Syaipudin, L. 2020).

Kondisi lingkungan yang bersih dan sehat sangat diperlukan dalam proses belajar mengajar agar tercipta lingkungan yang kondusif. Selain itu juga perlu ditunjang dengan perilaku yang sehat agar lingkungan yang ada dapat terpelihara dengan baik. Oleh karena itu perlu suatu upaya edukasi kepada masyarkat khususnya para santri yang berada di lingkungan Pondok Pesantren Nurul Jadid tentang perilau hidup bersih dan sehat. Dengan adanya kegiatan pengabdian masyarakat ini diharapkan dapat meningkatkan kesadaran para santri dalam menghadapi pandemi Covid-19 sehingga dapat melakukan upaya pencegahan dengan maksimal.

\section{Metode}

Metode kegiatan Pengabdian Kepada Masyarakat (PKM) ini adalah melakukan pelatihan dan pendampingan sosialisasi perilaku hidup sehat santri PP. Nurul Jadid Paiton Probolinggo di masa New Normal melalui 
berbagai media yang dapat diakses, difahami dan dipraktikkan oleh santri dengan mudah. Berikut gambar tahapan-tahapan program pelaksanaan kegiatan PKM.

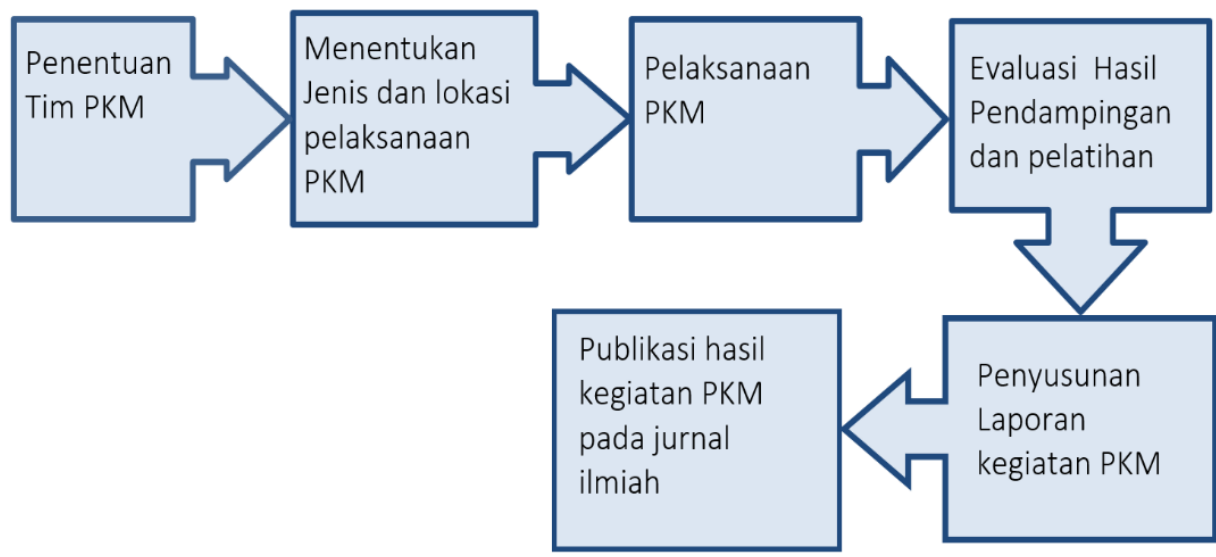

Gambar 1. Tahapan Pelaksanaan Pengabdian Kepada Masyarakat (PKM)

Penjelasan mengenai setiap tahapan kegiatan Pelaksanaan Pengabdian kepada Masyarakat (PKM) sebagai berikut :

1. Pembentukan Tim PKM dilakukan dengan melibatkan pengelola Klinik Azzainiyah PP. Nurul Jadid, dosen tetap dan mahasiswa Universitas Nurul Jadid yang terdiri dari 8 anggota yaitu 2 orang pengurus klinik Azzainiyah sebagai fasilitator, 1 dosen pembimbing yang berperan sebagai konseptor sekaligus tutor serta dibantu oleh 10 orang mahasiswa.

2. Tim KKN PKM menentukan materi pendampingan dan pelatihan serta melakukan pemetaan sasaran peserta sosialisasi dan pelatihan secara merata dan menyeluruh serta penentuan tempat dan lokasi kegiatan PKM yang sesuai dengan tema dan materi PKM agar tepat sasaran.

3. Pelaksanaan kegiatan PKM di PP. Nurul Jadid Paiton dengan melakukan pendampingan, sosialisasi secara langsung kepada pengurus dan santri serta pelatihan pembuatan konten kreatif pola hidup sehat santri berupa tulisan, gambar, serta video.

4. Melakukan evaluasi terhadap semua target kegiatan PKM.

5. Penyusunan laporan kegiatan PKM sebagai bukti pertanggungjawaban program. 
6. Publikasi kegiatan pengabdian kepada masyarakat dalam jurnal ilmiah yang bertujuan untuk menambah referensi ilmiah yang terkait dengan pelaksanaan pengabdian kepada masyarakat khususnya teknik sosialasasi dan pembuatan konten kreatif pola hidup sehat di masa New Normal bagi santri.

\section{Hasil}

Sebagai wujud untuk mencegah penularan Covid-19 di lingkungan santri PP. Nurul Jadid melalui sosialisasi pola hidup sehat secara langsung maupun sosialisasi melalui konten-konten kreatif berbasis digital di masa New Normal, maka target dan luaran yang dihasilkan dari kegiatan Pengabdian kepada Masyarakat ini dapat dilihat pada Tabel berikut.

Tabel 1. Target dan luaran program pengabdian

\begin{tabular}{|c|c|c|}
\hline & Target & Luaran \\
\hline 1. & $\begin{array}{l}\text { Memberikan pelatihan dan pendam- } \\
\text { pingan kepada Gugus Covid dan pe- } \\
\text { ngurus PP. Nurul tentang cara sosial- } \\
\text { isasi pola hidup sehat kepada santri. }\end{array}$ & $\begin{array}{l}\text { 1. Pemahaman pengurus PP. Nurul Jadid } \\
\text { tentang teknik sosialiasi pola hidup } \\
\text { sehat kepada santri yang kreatif, efektif } \\
\text { dan efisien. }\end{array}$ \\
\hline 2. & $\begin{array}{l}\text { Memberikan pelatihan kepada Gugus } \\
\text { Covid dan pengurus PP. Nurul Jadid } \\
\text { tentang cara membuat konten kreatif } \\
\text { sebagai media sosialisasi pola hidup } \\
\text { sehat santri. }\end{array}$ & $\begin{array}{l}\text { 2. Gugus Covid dan pengurus PP. Nurul } \\
\text { Jadid memeiliki katerampilan dalam } \\
\text { membuat berbagai macam konten } \\
\text { kreatif media sosialisasi pola hidup } \\
\text { sehat kepada santri yang menarik dan } \\
\text { mudah difahami serta dipraktikkan. }\end{array}$ \\
\hline 3. & $\begin{array}{l}\text { Melakukan pendampingan penyusunan } \\
\text { rencana dan pelaksanaan program } \\
\text { kegiatan yang sinergi tentang pola } \\
\text { hidup sehat santri dalam kehidupan } \\
\text { sehari-hari di pesantren. }\end{array}$ & $\begin{array}{l}\text { 3. Santri PP. Nurul Jadid dapat } \\
\text { melaksanakan pola hidup sehat dalam } \\
\text { program kegiatan rutin harian di } \\
\text { lingkungan pesantren. }\end{array}$ \\
\hline & $\begin{array}{l}\text { Membuat konten/media kreatif pola } \\
\text { hidup sehat di masa pandemi Covid-19 } \\
\text { berupa gambar, tulisan, video atau } \\
\text { konten lainnya yang menarik dan } \\
\text { mudah difahami. }\end{array}$ & $\begin{array}{l}\text { 4. Berbagai macam media kreatif gambar, } \\
\text { tulisan, video yang dapat diakses oleh } \\
\text { santri dan masyarakat tentang pola } \\
\text { hidup sehat di masa pandemi Covid-19. }\end{array}$ \\
\hline & $\begin{array}{l}\text { Kemampuan berkreatifitas dan pola } \\
\text { pikir dalam menciptakan dan } \\
\text { memanfaatkan berbagai macam } \\
\text { media/alat sosialisasi pola hidup sehat } \\
\text { kepada santri. }\end{array}$ & $\begin{array}{l}\text { 5. Pengurus dan Gugus Covid PP. Nurul } \\
\text { Jadid dapat menggunakan serta } \\
\text { menyebarluaskan media sosialisasi pola } \\
\text { hidup sehat kepada santri dan juga } \\
\text { masyarakat. }\end{array}$ \\
\hline
\end{tabular}


Dalam mencapai target dan luaran yang sudah ditetapkan dalam kegiatan PKM ini maka tim PKM bersama mitra-mitra terkait melakukan kegiatan sesuai dengan tahap-tahap sebagai berikut:

\section{1) Pembentukan Tim}

Agar pelaksanaan kegiatan PKM ini berjalan dengan baik dan dapat mencapai tujuan yang diinginkan, maka pembentukan tim harus disesuaikan dengan kebutuhan kompetensi berdasarkan rencana program yang akan dilaksanakan. Oleh karena itu pembentukan tim pelaksana PKM ini selain melibatkan mahasiswa dari berbagai bidang keilmuan Prodi juga melibatkan beberapa mitra diantaranya tenaga kesehatan klinik azzainiyah dan pengurus PP. Nurul Jadid.

Keterlibatan tenaga kesehatan klinik Azzainiyah dalam tim pelaksana PKM ini sangatlah dibutuhkan, khususnya dalam memberikan masukanmasukan terkait konsep pola hidup sehat sesuai dengan kondisi kesehatan dan pola hidup keseharian santri PP. Nurul Jadid. Selain itu, tenaga kesehatan klinik Azzainiyan sangat relevan perannya dalam penyusunan konsep dan materi sosialiasi pola hidup sehat santri karena sinergi dengan tugas dan tanggungjawabnya yaitu memberikan pelayanan kesehatan santri sekaligus lembaga yang membawahi Gugus Covid PP. Nurul Jadid.

Mitra lain yang dilibatkan dalam tim pelaksana PKM ini adalah Pengurus Pesantren PP. Nurul Jadid khususnya pengurus Biro Kepesantrenan yang bertanggungjawab terhadap seluruh program rutin harian santri di lingkungan pesantren dan juga melibatkan pengurus Biro Pendidikan yang bertanggungjawab terdahap program kegiatan santri di lembaga pendidikan formal. Dengan adanya keterlibatan pengurus pesantren proses pemetaan proses sosialisasi secara merata dan menyeluruh dapat terlaksana, yang tidak kalah pentingnya bahwa keberlanjutan dalam mencipkatan pola hidup sehat santri secara konsisten adalah pengurus pesantren. 
Berdasarkan pertimbangan sebagaimana uraian di atas, maka tim PKM berdasarkan analisis kebutuhan kompetensi sesuai dengan target dan tujuan PKM adalah terdiri dari 13 orang yaitu 1 orang dosen pembimbing yang berperan sebagai tutor dan konseptor, 1 orang tenaga kesehatan sebagai fasilitator dan konsultan, 2 orang pengurus pesantren Biro Pendidikan dan Biro Kepesantrenan dan 10 orang mahasiswa dengan berbagai kompetensi dan bidang keilmuan sesuai kebutuhan program.

2) Penyusunan Materi dan Penentuan Lokasi Pelaksanaan Berbasis Pemerataan

Penyusunan materi pendampingan dan pelatihan dilakukan oleh seluruh tim pelaksana melalui sistem diskusi, musyawaran dan jajak pendapat. Masing-masing tim menyampaikan berbagai usulan dan masukan sesuai dengan kompetensinya, misalnya tenaga kesehatan memberikan masukan tentang konsep pola hidup di masa new normal sesuai kondisi dan kebiasaan santri. Dari masukan tersebut diharapkan materi pendampingan dan pelatihan dapat disusun sesuai dengan standar kesehatan dan memungkinkan untuk dilaksanakan oleh santri PP. Nurul Jadid.

Tim pelaksanan dari unsur pengurus pesantren dalam penyusunan materi ini memberikan gambaran dan masukan terkait program dan kegiatan rutin harian santri di pesantren maupun di lembaga pendidikan, menyampaikan kondisi pola hidup santri terkini serta informasi lain yang relevan dan mendukung terhadap perumusan materi dan pelaksanaan program PKM ini sehingga setelah proses sosialisasi, pendampingan dan pelatihan dilaksanakan, konsep pola hidup sehat santri PP. Nurul Jadid bisa diwujudkan dalam kehidupan sehari-hari dan terintegrasi ke dalam program pesantren dan lembaga pendidikan secara berkesinambungan dan berkelanjutan.

Adapun peran mahasiswa dalam proses penyusunan materi ini sama dengan anggota tim yang ini yaitu memberikan masukan sesuai bidang ilmu dan kompetensinya, misalkan mahasiswa dari Prodi Teknik Informatika memberikan gambaran dan masukan terkait materi pelatihan pembuatan konten kreatif gambar atau video menggunakan aplikasi yang mudah dan sederhana. Mahasiswa dari Prodi Komunikasi Penyiaran Islam memberikan masukan tentang bagaimana teknik 
sosialiasi dengan model ceramah dan diskusi serta praktik yang menyenangkan dan mudah dilakukan.

Berbagai informasi dan masukan yang telah disampaikan oleh seluruh anggota tim, referensi dari buku dan artikel yang relevan dijadikan sebagai dasar penyusunan materi pendampingan dan pelatihan PKM ini, serta menjadi acuan untuk merumuskan tahapan-tahapan dan penentuan lokasi pelaksanaan program PKM agar dapat dilaksanakan secara merata kepada seluruh santri PP. Nurul Jadid. Pemetaan lokasi tempat dalam pelaksanaan PKM ini sangatlah penting, mengingat tempat pemondokan santri tersebar di beberapa lokasi yang berbedabeda.

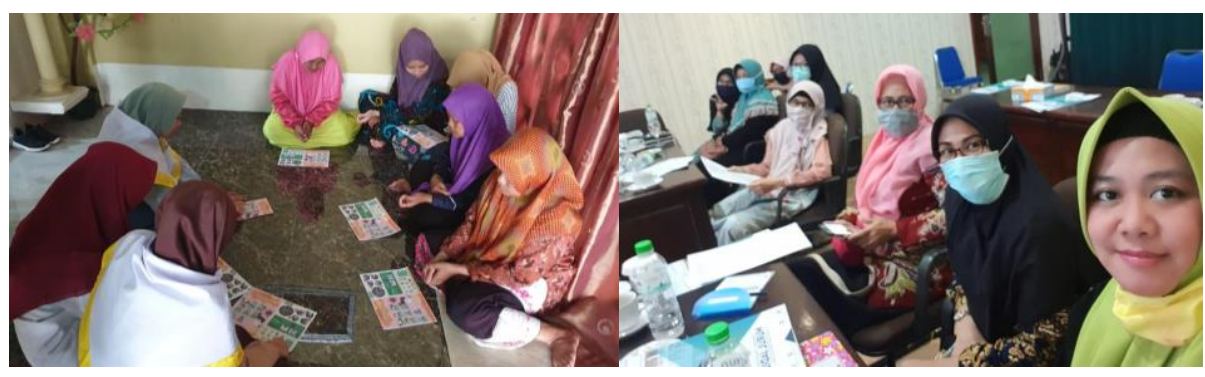

Gambar 2. Dokumentasi Proses Penyusunan Materi

3) Pelaksanaan kegiatan PKM

Pelaksanaan PKM ini dibagi ke dalam 3 (tiga) jenis kegiatan yaitu; pelatihan, sosialisasi, dan pendampingan. Adapun uraian masing-masing kegiatan PKM ini adalah sebagai berikut:

a. Kegiatan Pelatihan

Kegiatan pelatihan ini dilakukan untuk mengasah keterampilan pengurus dan anggota gugus covid PP. Nurul Jadid dalam membuat berbagai macam konten kreatif media sosialisasi pola hidup sehat kepada santri yang menarik dan mudah difahami serta dipraktikkan. Bentuk dari kegiatan ini adalah pelatihan dengan cara praktik membuat konten informasi berupa video maupun desain grafis. Aplikasi yang digunakan dalam pelatihan ini antara lain Filmora untuk pelatihan videografi dan photoshop untuk pelatihan desain grafis serta aplikasi desain online yaitu canva. Ketiga aplikasi ini dipilih karena dianggap lebih mudah dioperasikan dan dipahami oleh peserta pelatihan. 
Berbagai macam video dan desain informasi pola hidup sehat yang dihasilkan dari pelatihan ini diantaranya, pamflet informasi tentang cara mencuci tangan, cara memakai masker, pola hidup bersih dan media informasi lainnya. Hasil karya ini kemudian di tempel dan dipasang ditempat-tempat strategis sebagai media sosialisasi sekaligus pengingat santri agar mematuhi protokol kesehatan dan selalu menjaga pola hidup sehat dalam kehidupan sehari-hari. Berikut beberapa media sosialisasi dan informasi yang dihasilkan dari kegiatan pelatihan ini.

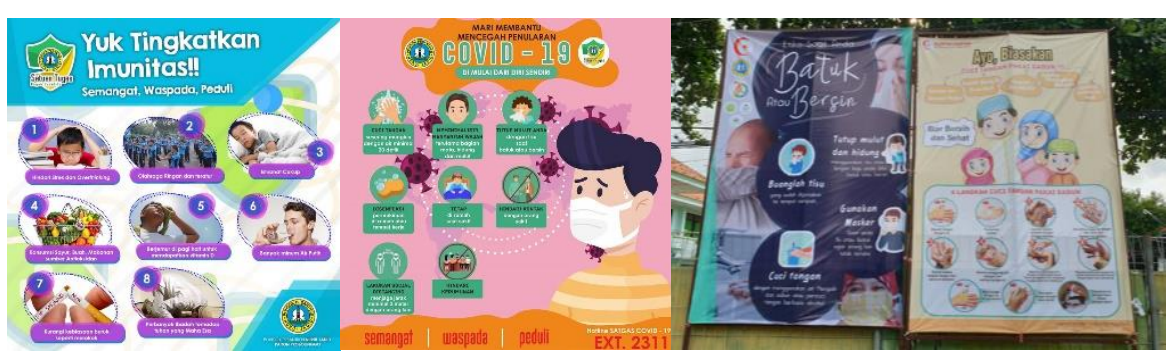

Gambar 3. Dokumentasi hasil pelatihan pembuatan media sosialisasi

b. Kegiatan Sosialisasi.

Yang dimaksud dengan kegiatan sosialisasi ini adalah kegiatan tatap muka langsung antara tutor dan peserta (santri) tentang pola hidup sehat di pesantren. Agar kegiatan sosialisasi ini berjalan secara efektif dan dapat secara rutin dilakukan kepada santri, maka sasaran utama sosialisasi ini adalah pengurus pesantren dengan target semua pengurus dapat memahami dan mempraktikkan bagaimana cara melakukan sosialisasi langsung kepada santri di berbagai wilayah secara menyeluruh dengan memanfaatkan media praktik agar lebih mudah difahami.

Setelah sosialisasi kepada pengurus selesai, tahap selanjutnya adalah menyusun rencana sosialisasi serta mempersiapkan seluruh perangkat dan media sosialisasi yang akan dikepada santri di 7 (tujuh) wilayah PP. Nurul Jadid secara menyeluruh. Nara sumber dalam sosialisasi tahap kedua ini adalah seluruh pengurus yang telah mengikuti sosialisasi tahap pertama, kemudian tindak lanjut dari sosialisasi ini adalah mengintegrasikan program-program kegiatan rutin santri dengan pola hidup sehat dilingkungan pesantren. 


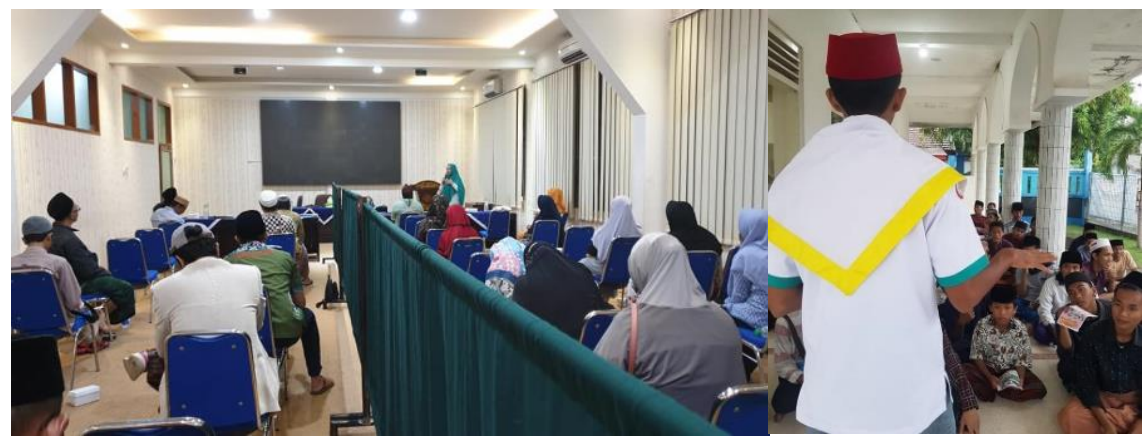

Gambar 4. Dokumentasi sosialisasi kepada pengurus dan santri

c. Kegiatan Pendampingan

Agar penerapan pola hidup sehat di PP. Nurul Jadid dapat terlaksana secara konsisten dan berkelanjutan, selanjutnya tim melakukan pendampingan kepada pengurus dan petugas gugus covid 19 untuk menyusun program integrasi pola hidup sehat dengan kegiatan rutin santri di lingkungan pesantren maupun lembaga pendidikan PP. Nurul Jadid. Dengan adanya program integrasi tersebut diharapkan santri dapat menerapkan dan melatih diri untuk terus berprilaku sehat dalam kehidupan sehari-harinya selama ada di pesantren maupun saat pulang kembali ke masyarakat.

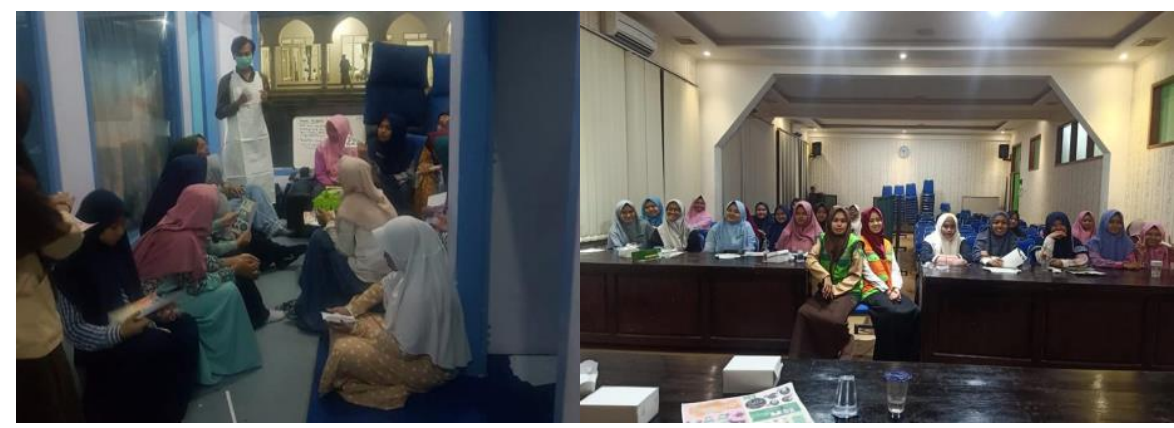

Gambar 5. Dokumentasi pendampingan penyusunan program pola hidup sehat

4) Melakukan Evaluasi Kegiatan PKM

Untuk mengetahui tingkat ketercapaian target dan mengindentifikasi pemasalahan serta kendala yang muncul dalam kegiatan PKM ini, maka tim bersama mitra melakukan kegiatan evaluasi. Hasil evaluasi ini selanjutnya akan dijadikan sebagai acuan dalam menyusun rencana tindak lanjut program. 
Dari hasil evaluasi didapatkan laporan bahwa kegiatan sosialisasi pola hidup sehat santri di masa new normal telah dilakukan secara menyeluruh di 7 (wilayah) PP. Nurul Jadid. Selain dilakukan secara tatap muka langsung dan diskusi, kegiatan sosialisasi juga dilakukan menggunakan berbagai media informasi seperti pamflet dan lain-lain yang dipasang di tempattempat strategis seperti depan kamar santri, koperasi makan, lembaga pendidikan, jalan umum santri, dan tempat strategis lainnya. Media informasi tersebut dibuat dengan desain yang menarik, jelas dan mudah difahami oleh seluruh santri. Dengan adanya program integrasi pola hidup sehat dengan kegiatan rutin santri, kegiatan sosialisasi ini tidak hanya memberikan pemahaman kepada santri saja namun santri sudah mampu menerapkan pola hidup sehat dalam kehidupan sehari-hari mereka di lingkungan pesantren maupun lembaga pendidikan PP. Nurul Jadid. Selanjutnya hasil evaluasi ini juga dijadikan sebagai bahan untuk koreksi untuk pembuatan laporan kegiatan PKM dan sebagai dasar referensi untuk penyusunan artikel ilmiah yang akan dipublikasikan.

\section{Pembahasan}

Saat ini Indonesia sedang mengalami Pandemic Covid-19. Covid-19 merupakan suatu penyakit menular yang disebabkan oleh coronavirus yang baru ditemukan. Menurut World Health Organization (WHO), bahwa virus corona dapat menginfeksi pada sistem pernafasan yang dapat di identifikasi seperti penyakit flu biasa sampai penyakit pernafasan yang semakin parah. Virus corona atau Covid-19 dapat ditularkan antara hewan dan manusia. Berdasarkan Kementerian Kesehatan Indonesia yang dikutip oleh Hanoatubun (2020) bahwa Covid-19 telah ada di Wuhan Municipal Health Committee pada tanggal 30 Desember 2019 sampai tersebar ke 188 negara yang terkonfirmasi kena virus Corona. Covid-19 oleh WHO dinyatakan sebagai Pandemi dan menyebabkan perubahan dalam tatanan kehidupan manusia (Yayuk Hidayah, Nufikha Ulfah, 2019) begitupun kehidupan santri di pesantren. Situasi ini kemudian dianggap perlu untuk dilakukan antisipasi, termasuk beradaptasi melalui keadaan new normal (Yang, 2020).

Istilah new normal sudah dikenal sejak lama dalam kajian ilmu ekonomi (Storm, 2017; Ahlstrom et al., 2020). New normal didasari oleh keadaan ekonomi yang secara luas yang didiagnosis karena munculnya stagnasi dan 
ketidakseimbangan terhadap pertumbuhan maupun penghasilan (Storm, 2017). Lingkungan normal baru (New Normal) telah muncul pada tahuntahun setelah tahun 2008 pada krisis keuangan yang didasarkan pada berbagai perubahan dalam sektor ekonomi, teknologi, demografi, dan sosial politik dunia. Kombinasi perubahan ini telah menciptakan lingkungan serta normalisasi baru (Ahlstrom et al., 2020).

Dalam melaksanakan masa kenormalan baru ini santri di pesantren juga harus turut serta berperan aktif dan menaati protokol kesehatan yang telah ditetapkan oleh pemerintah agar penyebaran Covid-19 dapat diminimalisir, salahsatunya dilakukan dengan cara menciptakan lingkungan yang bersih dan pola hidup sehat. Lingkungan yang bersih dan sehat berarti harus bebas dari virus, bakteri dan berbagai vektor penyakit serta bebas dari bahan kimia berbahaya. Namun, masalah kebersihan dan kesehatan lingkungan selalu menjadi polemik di pesantren. Karena kondisi lingkungan yang kurang bersih, banyak penyakit menular yang menyebar sangat cepat di kalangan santri. Darmawan dalam penelitiannya mengatakan bahwa masyarakat yang tinggal di daerah pemukiman kumuh mempunyai kejadian penyakit menular dan kecelakaan dalam rumah yang lebih tinggi dibandingkan dengan mereka yang tinggal di lingkungan pemukiman yang lebih baik (Darmawan, 2016).

Dalam kegiatan PKM ini diperoleh informasi bahwa PP. Nurul Jadid telah melakukan berbagai upaya untuk mencegah penyebaran virus corona, diantaranya pembentukan tim gugus covid pesantren, menerapkan social distancing dengan cara menutup kunjungan tamu dan wali santri ke pesantren, menyediakan kelengkapan sarana dan prasarana sterilisasi, melaksanakan pembelajaran secara daring, menyediakan gedung khusus isolasi mandiri bagi santri yang sakit dan berbagai upaya lainnya. Namun berbagai upaya yang telah dilakukan belum mendapatkan dukungan secara optimal dari pengurus dan santri PP. Nurul Jadid. Kebanyakan santri belum memahami tentang pola hidup sehat di masa new normal, masih banyak santri membuang sampah sembarangan, tidak disiplin memakai masker, saling meminjam pakaian orang lain, menumpuk pakaian kotor, tidur larut malam dan sebagainya.

Selain kurangnya pemahaman santri dalam menerapkan pola hidup sehat, pengurus PP. Nurul Jadid juga belum secara masif melakukan sosialisasi secara rutin kepada santri yang bisa dipahami dan dipraktikkan secara mudah. Beberapa program kegiatan rutin santri juga belum terintegrasi 
dengan konsep pola hidup sehat sehingga aktifitas keseharian santri masih berjalan seperti biasanya.

Beberapa langkah dan upaya dapat dilakukan oleh pengurus dan santri untuk mendukung kebijakan pesantren dan pelaksanaan program gugus covid dalam mencegah penyebaran covid-19 di lingkungan PP. Nurul Jadid diantaranya dengan cara membekali pengurus agar memiliki konsep dan pengetahuan agar terampil dalam menciptakan berbagai media informasi dan melakukan sosialisasi kepada santri dengan cara yang mudah dipahami dan menyenangkan. Agar hasil sosialisasi pola hidup sehat dapat diimplementasikan, maka perlu dilakukan diintegrasikan pola hidup sehat dengan program kegiatan rutin santri di pesantren maupun lembaga pendidikan PP. Nurul Jadid.

Hasil yang diperoleh dari kegiatan PKM ini diantaranya; melalui kegiatan pelatihan pembuatan media sosialiasi, pengurus memiliki kemampuan dalam membuat berbagai macam media sosialisai baik dalam bentuk video maupun desain grafis. Media informasi dan sosialisasi itu dibuat dengan desain yang menarik dan mudah dipahami seluruh kalangan santri, penyebaran media informasi tersebut juga telah diletakkan di tempat-tempat strategis yang mudah dilihat dan dibaca oleh santri. Selain telah memiliki kecakapan dalam membuat media sosialisai pola hidup sehat, pengurus juga mulai kreatif menciptakan konten lain untuk menyampaikan motivasi dan pesan kepada wali santri melalui media sosial. Berikut salahsatu contoh konten kreatif pengurus PP. Nurul Jadid yang telah diunggah di media sosial.

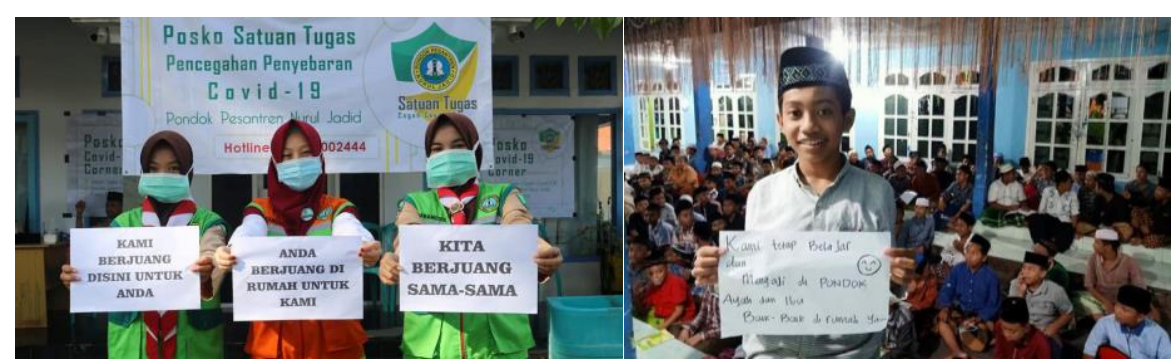

Gambar 6. Dokumentasi konten kreatif yang dibuat pengurus

Hasil kegiatan sosialisasi langsung kepada santri PP. Nurul Jadid yang dilakukan oleh pengurus dan didampingi tim PKM dengan berbagai media serta materi dan panduan yang telah disusun bersama. Sosialisasi dilakukan dengan model ceramah, praktik dan diskusi telah diikuti oleh santri PP. Nurul 
Jadid secara menyeluruh di 7 (tujuh) wilayah terpisah. Melalui sosialisasi langsung ini santri bisa melakukan praktik secara langsung tentang berbagai cara pola hidup sehat seperti mencuci tangan, memakai masker, mencuci pakaian, menu makanan bergizi dan praktik lainnya. Selain itu santri bisa langsung menanyakan materi-materi yang belum dipahami atau dirasa kurang bisa dimengerti, sehingga santri PP. Nurul Jadid bisa utuh memahami semua materi yang disampaikan.

Untuk kegiatan pendampingan hasil yang didapat adalah tersusunnya program kegiatan rutin santri PP. Nurul Jadid terintegrasi dengan pola hidup sehat. Dengan program ini rutinitas keseharian santri dan lembaga pendidikan telah sepenuhnya menerapkan pola hidup sehat, mulai pengaturan jam mandi, mencuci baju, menu makanan, pembatasan aktifitas, jam tidur santri, kegiatan rutin olah raga pagi dan program rutinitas lainnya. Dengan demikian program PKM ini tidak hanya selesai di waktu tertentu saja, namun dapat terus berlanjut sebagai konsep pola hidup sehat santri di PP. Nurul Jadid.

\section{Kesimpulan}

3 (tiga) jenis kegiatan yaitu pelatihan, sosialisasi dan pendampingan pengurus dan santri PP. Nurul Jadid untuk mewujudkan pola hidup sehat santri di masa new normal ini telah sesuai dengan target dan luaran yang telah ditetapkan. Hal ini sudah dapat terlihat pada peningkatan pengetahuan dan keterampilan pengurus dalam menciptakan berbagai media informasi dan sosialisasi yang menarik dan mudah dipahami oleh santri. Pengurus PP. Nurul Jadid juga telah memiliki pengetahuan dan pengalaman menyusun konsep materi dan menjadi tutor sosialisasi pola hidup sehat santri. Melalui kegiatan sosialisasi, santri memiliki pemahaman pola hidup sehat dan mempraktikkannya dalam kegiatan rutin sehari-hari di pesantren dan lembaga pendidikan PP. Nurul Jadid. Impelementasi hasil pelatihan dan sosialisai dalam kegiata PKM ini juga telah diintegrasikan dalam program kegiatan rutin santri dan telah menjadi bagian dari sistem kebijakan pesantren. 


\section{Pengakuan}

Tim KKN PKM mengucapkan terimakasih banyak atas kerjasamanya kepada seluruh pengurus dan santri PP. Nurul Jadid, Tim Gugus Civod PP. Nurul Jadid, Pengurus Klinik Azzainiyah, selaku mitra pada pelaksanaan PKM ini. Terima juga disampaikan kepada seluruh pengurus LP3M Universitas Nurul Jadid yang telah memberi amanah kepada tim PKM untuk melaksanakan kegiatan pelatihan, sosialisasi dan pendampingan pola hidup sehat di masa new normal sebagai dampak pandemi covid-19 di PP. Nurul Jadid.

\section{Referensi}

Ahlstrom, D., Arregle, J. L., Hitt, M. A., Qian, G., Ma, X., \& Faems, D. (2020). Managing technological, sociopolitical, and institutional change in the new normal. Journal of Management Studies, 57(3), 411-437.

Astawan, M, (2020), Sehat dengan Rempah dan bumbu dapur, Buku Kompas, Jakarta.

Habibi, A. (2020). Normal Baru Pasca Covid-19, 'Adalah: Buletin Hukum dan Keadilan, 4(1), pp. 197-202.

Hanoatubun, S. (Volume 2 Nomor 1 (2020) ). Dampak Covid - 19 Terhadap Perekonomian Indonesia. Journal of Education, Psychology and Counseling, 147-148.

Isbaniah, F. et al. (2020). Pedoman Pencegahan dan Pengendalian Coronavirus Disease (COVID-19) Revisi ke-4, Kementerian Kesehatan RI. Jakarta: Kementerian Kesehatan RI.

Kemenkes RI, (2020). Panduan Pencegahan Pengendalian COVID-19 di Perkantoran dan Industri. No. HK.01.07/MENKES/328/2020. Jakarta

Kemenkes., (2020), PHBS Direktorat Promosi Kesehatan Dan Pemberdayaan Masyarakat; 2020 [cited 2020 4]; Available from: https://promkes.kemkes.go.id/phbs.

S. Y. Amijaya, T. Seliari, and K. Oentoro, "Pengembangan Strategi Pemasaran Dan Promosi Produk Umkm Di Tengah Pandemi Covid-19," Proceeding Senadimas ..., 2020, [Online]. 
Storm, S. (2017). The new normal: Demand, secular stagnation, and the vanishing middle class. International Journal of Political Economy, 46(4), 169-210.

Ting, D. S. W., Carin, L., Dzau, V., \& Wong, T. Y. (2020). Digital technology and COVID-19. Nature medicine, 26(4), 459-461.

Wahyuddin W. Kontribusi Pondok Pesantren Terhadap NKRI. SAINTIFIKA ISLAMICA: Jurnal Kajian Keislaman. 2017;3(01):21-42.

Wahyuddin W. Kontribusi Pondok Pesantren Terhadap NKRI. SAINTIFIKA ISLAMICA: Jurnal Kajian Keislaman. 2017;3(01):21-42.

Yayuk Hidayah, Nufikha Ulfah, S. (2019). JPK : Jurnal Pancasila dan Kewarganegaraan. Jurnal Pancasila Dan Kewarganegaraan, 4(2), 2233. https://doi.org/10.24269/jpk.v4.n2.2019 